\title{
Ecological studies on macroinvertebrate populations associated with polluted kelp forests in the North Sea
}

\author{
D. J. JONES \\ Department of Botany, University of Durbam; Durham, England
}

\begin{abstract}
KURZFASSUNG: Okologische Studien an Populationen von Makro-Invertebraten auf verunreinigten Seetang-Wäldern in der Nordsee. Die Arbeit berichtet über erste Ergebnisse einer ökologischen Untersuchung an verschmutzten Küstengewässern im Bereich der Grafschaften Durham und Midlothian (im Nordosten Englands). Die untersuchten Küstenstreifen enthalten sowohl städtische als auch industrielle Gebiete, während die dazwischenliegende Landmasse weitgehend landwirtschaftich genutzt wird. Die Küstengewässer in Durham sind seit über 100 Jahren verschmutzt, d. h. seit dem Beginn der industriellen Revolution. Das Ausmaß der Verschmutzung wird kurz umrissen. Es wird eine Methode beschrieben, die einen Vergleich der in den verschmutzten Seetang-Gebieten gewöhnlich anzutreffenden Invertebraten-Epifauna ermöglicht. Repräsentative Proben der auf dem Haftorgan der Braunalge Laminaria byperborea lebenden Fauna wurden gesammelt und mit Proben aus unverseuchten Gewässern verglichen. Die Ergebnisse deuten an, daß in verschmutzten Gewässern die Artenfolge, die Geschwindigkeit der Aufeinanderfolge, die Häufigkeit der Individuen und die trophische Struktur der Lebensgemeinschaft verändert sind. In verschmutzten Gewässern ist die Entwicklung zu komplexen Lebensgemeinschaften verlangsamt; es entstehen "neotene" Gemeinschaften. Gründe, welche einer Entwicklung zu einer normalen Lebensgemeinschaft im Wege stehen, werden herausgestellt.
\end{abstract}

\section{INTRODUCTION}

One feature of the East coast of Britain is the concentration of heavy industry around the lower reaches of the Rivers Forth, Tyne, Wear and Tees. Industrialisation, with its attendant development of large urban populations, has gone hand in hand with the production of an increasing amount of waste material which is voided into the sea. Man's activities in this direction may be broadly considered in two categories: (1) Man as a geomorphological force speeding up the transport of terrigenous material to the sea. (2) Man as a geochemical force manufacturing substances which do not occur naturally anywhere in the crust and voiding them into the sea.

The result is pollution, which is defined here as the addition of anything to the sea which brings about disruption of the natural balance of the ecosystem present in the vicinity of the outfall. 
Beginning in 1967, an ecological survey of the inshore waters illustrated in Figure 1 was undertaken to assess biological damage to the marine environment from pollution of the sea. This paper presents the preliminary results of that study.

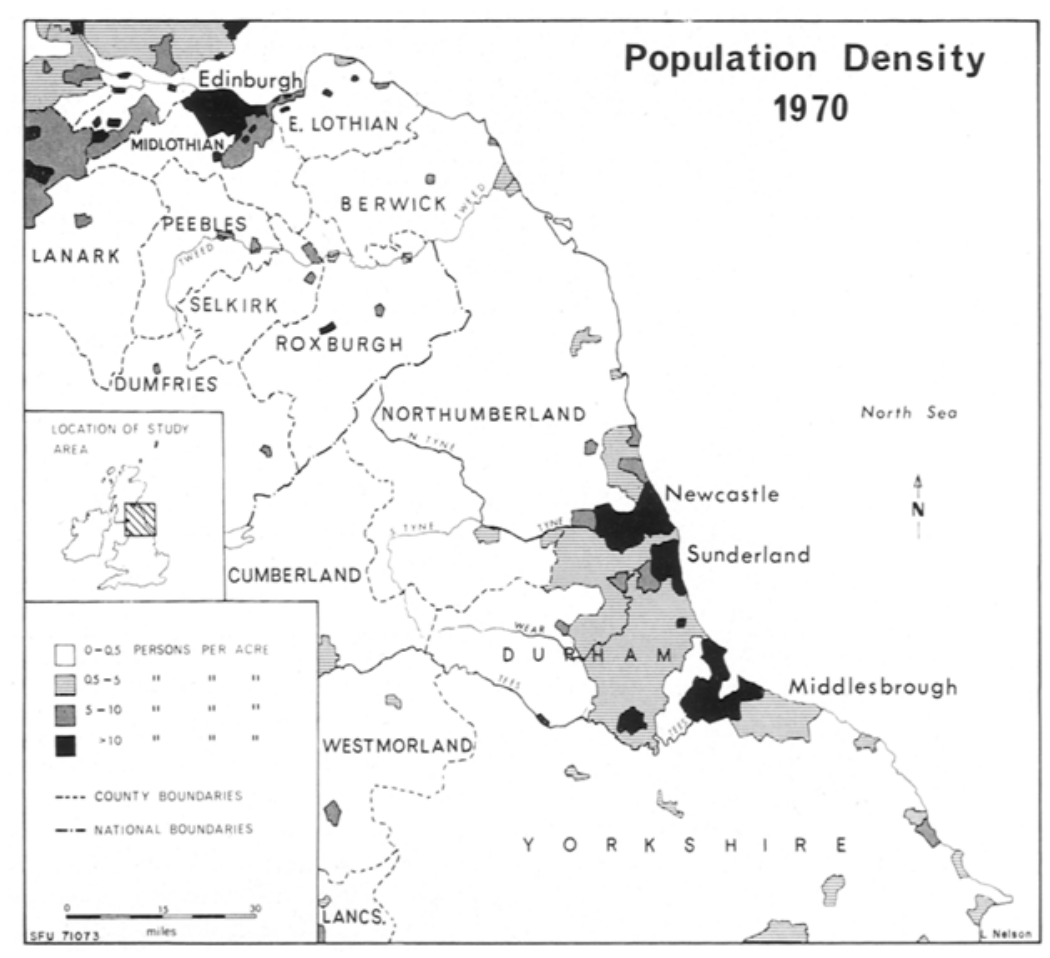

Fig. 1: Distribution of the urban population on the North East coast of Britain adjacent to the study area

\section{THE EXTENT OF MARINE POLLUTION IN THE NORTH EASTERN REGION OF THE NORTH SEA}

The human population density adjacent to the study area is shown in Figure 1. Marked aggregations can clearly be seen around the lower reaches of the River Forth in Scotland, and the Rivers Tyne, Wear and Tees in Co. Durham, England.

Figures 2 and 3 present a detailed analysis of the extent of industrial development along the lower reaches of the three main Co. Durham rivers (House 1969)* Industrial development of this area can be traced to the early days of the Industrial Revolution

* Reproduced by kind permission of Prof. J. W. House, Dept. of Geography, University of Newcastle upon Tyne and David and Charles (Holdings) Ltd., Devon. 

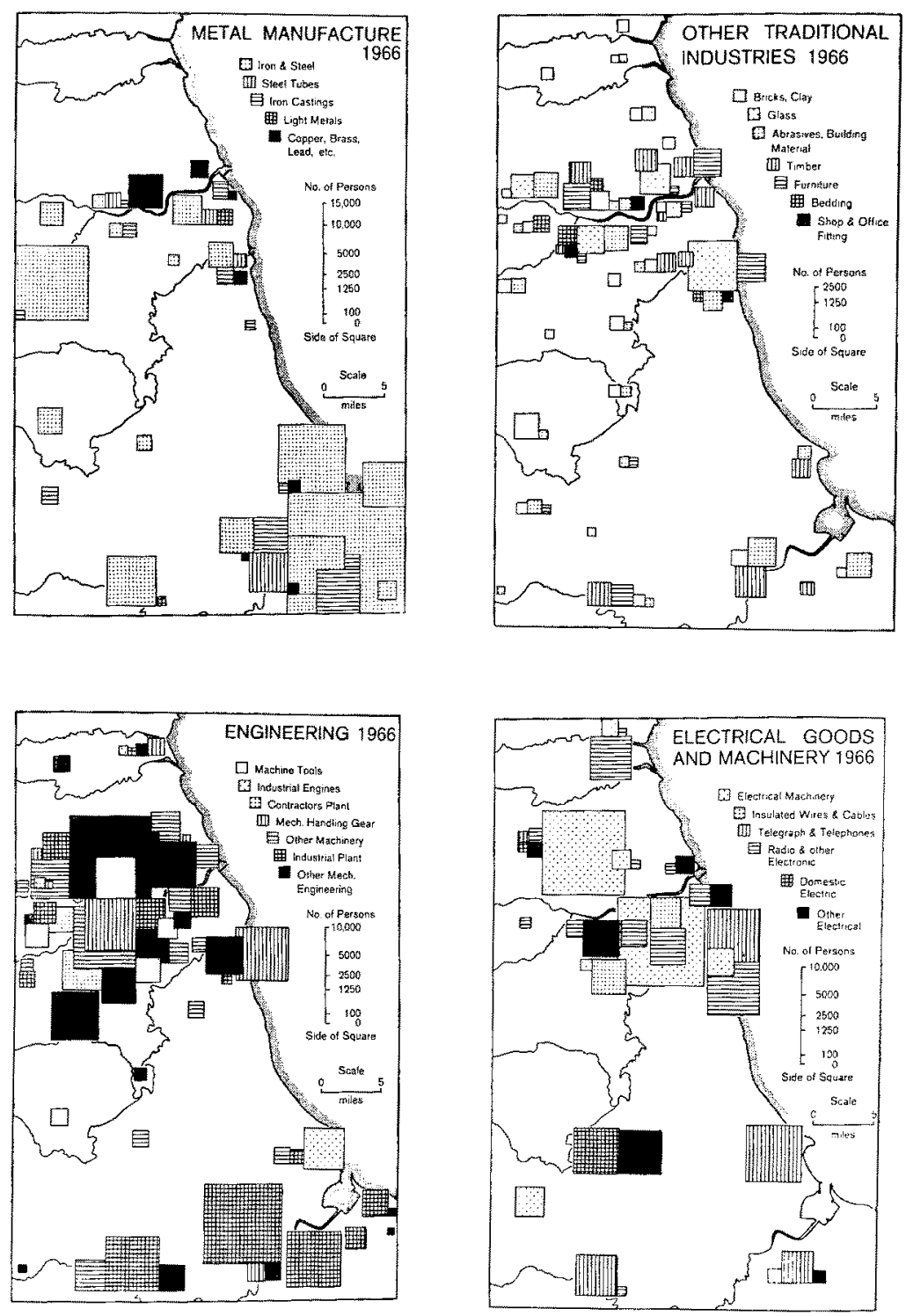

Fig. 2: Industrial development in Co. Durham

and for most of the intervening 150 years unknown and unmeasured amounts of industrial and domestic wastes have reached the sea via the rivers.

The length of coastline included in this survey and the location of sampling stations along it, are shown in Figure 4. The following a-biotic parameters illustrated in Tables 1 and 2 were obtained from the stations indicated. The extent of the pollution may be conveniently discussed under the following headings. 

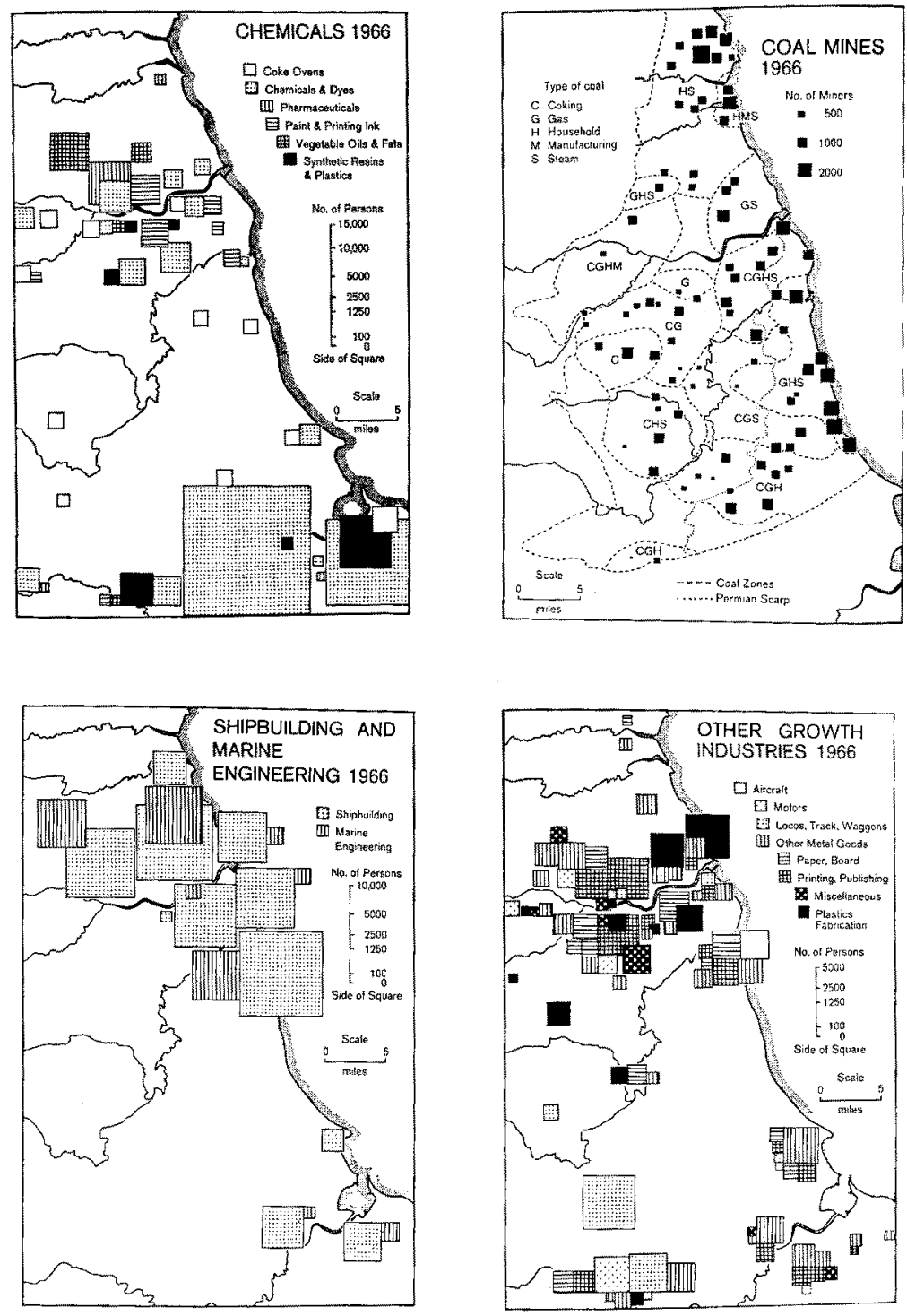

Fig. 3: Industrial development in Co. Durham

\section{Sewage pollution}

In the densely urban areas adjacent to Station 1 (Forth Bridge), Station 15 (Souter Point) and coastal waters between Station 16 (Seaham) and Station 17 (Robin Hoods Bay) faecal bacteria counts have been recorded in excess of 160,000 organisms per litre of sea water (Covill 1968, Beliamy 1968). By comparison, numbers of bacteria 
Polluted kelp forests in the North Sea

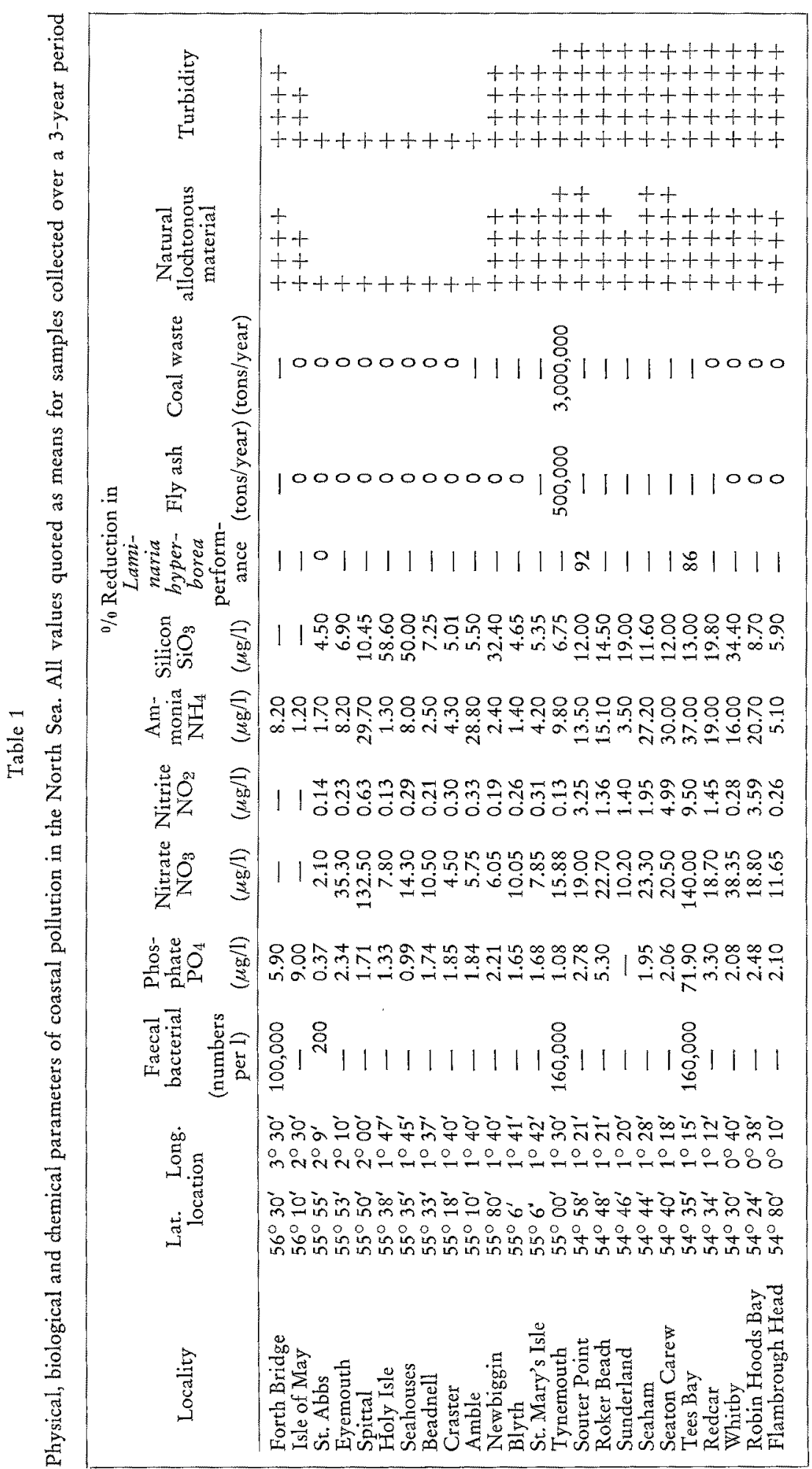




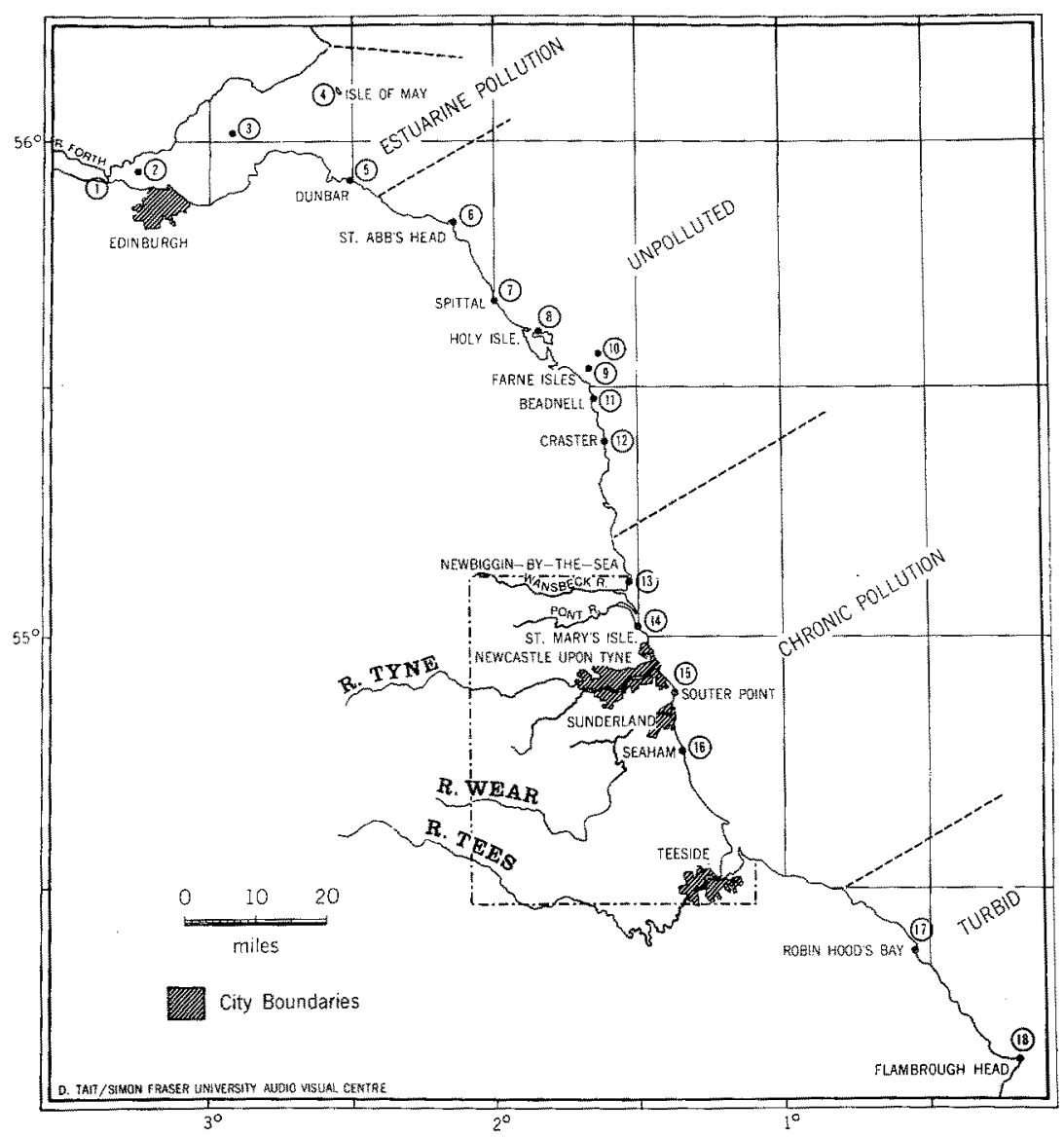

Fig. 4: Location of the sampling stations in the study area

counted in sea waters collected at Station 6 (St. Abbs) never exceeded 200 organisms per litre.

\section{Soluble inorganic nutrients}

Available inorganic nitrogen $\left(\mathrm{NO}_{3}, \mathrm{NO}_{2}+\mathrm{NH}_{4}\right)$, phosphate $\left(\mathrm{PO}_{4}\right)$ and silicon $\left(\mathrm{SiO}_{3}\right)$ can be rate limiting on plant growth in natural seawater (RAYMONT 1966). It is significant that along these shores, the highest levels of nitrate, phosphate and silicon in solution occur in the polluted coastal seas adjacent to the Rivers Tyne, Wear and Tees. However, erosion products from the land can enrich coastal seas adjacent to rivers, with inorganic nutrients and the decay products of organic material originating from the land mass (RIley 1937, Rees 1939, Harvey 1945, Kalle 1953). The addition of industrial and domestic pollutants to river systems can further increase nutrient levels in the vicinity of river estuaries (Renn 1956, Koch 1959, Odum 1961a, Jefrries 1962, 
Table 2

Analysis for heavy metals in sediments collected from interstices of holdfasts. (All values expressed as p.p.m.)

\begin{tabular}{|cccccccccc|}
\hline Station & $\mathrm{Pb}$ & $\mathrm{Zn}$ & $\mathrm{Cu}$ & $\mathrm{Ni}$ & $\mathrm{Ba}$ & $\mathrm{I}$ & $\mathrm{Zr}$ & $\mathrm{Sr}$ & $\mathrm{Br}$ \\
\hline 8 & 22 & 55 & 25 & 22 & 250 & 600 & 300 & 450 & 350 \\
11 & 17 & 40 & 15 & 20 & 200 & 450 & 150 & 700 & 550 \\
15 & 63 & 106 & 24 & 23 & 600 & 543 & 616 & 400 & 233 \\
\hline
\end{tabular}

CRONIN 1967). Thus there is every likelihood that a proportion of the high nutrient levels found in $\mathrm{Co}$. Durham coastal waters are a natural event, caused by erosion of the river catchment. However, a consideration of the intensive industry in this area must indicate that pollutants also contribute to the high levels of soluble inorganic nutrients found in the inshore waters of Co. Durham.

It is also possible that a proportion of the pollutants detected in the coastal seas have originated well inland, from urban and industrial conurbations on the middle reaches or even the headwaters of these rivers.

WATSON \& WATSON (1968) recorded nitrate $\left(\mathrm{NO}_{3}\right)$ levels of $177 \mu \mathrm{g} / 100 \mathrm{ml}$, phosphate at $95 \mu \mathrm{g} / 100 \mathrm{ml}$ and suspended solids in excess of $400 \mu \mathrm{g} / 100 \mathrm{ml}$ in Tees Bay. Similar trends in industrial and urban development along the rivers Tyne and Wear must also enrich these waters.

Phosphate levels of $2.78 \mu \mathrm{g} / 1$ at Station 15 (Souter Point) are over seven times higher than those at Station 6 (St. Abbs, Table 1). Total inorganic nitrates at Station 16 (Seaham) can reach $52.4 \mu \mathrm{g} / 1$ more than thirteen times higher than at Station 6. Silicon levels are twice as high at Station 16 (Seaham) compared with Station 6. Levels of all these nutrients at Station 6 (St. Abbs) are of the same order as the mean annual levels for more Northern regions of the North Sea which are not polluted (P. HEAD, pers. comm.). The inorganic nitrate levels in the naturally turbid waters at Station 17 (Robin Hoods Bay) fall between the normal low values in the unpolluted waters at Station 6 (St. Abbs) and the unnaturally high figures at Station 15 and 16 (Souter Point and Seaham). The erosion of boulder clay cliffs in this area is the source of much natural turbidity at Stations 17 and 18. It is possible that the increase in the levels of inorganic nutrients recorded here is associated with the natural turbidity of the waters.

Along the whole of the coastline under study, the indications are that pollutants added to the seas of Co. Durham increase the levels of inorganic nutrients found there and further enrich the coastal waters already receiving nutrient run-off and erosion products from the land, via the three rivers.

\section{Inert, inorganic pollutants}

The inshore waters adjacent to Co. Durham annually receive at least 3,000,000 tons of coal waste dropped directly into the sea from coastal mining operations. "The Times" 14th March, 1970). Up to 500,000 tons of flyash (from coal fired power stations) is tranfered into the sea a short distance from these shores. 


\section{Heavy metals as pollutants}

Heavy metal analysis of sediments collected in sublittoral kelp forests (Table 2) shows levels of the inorganic metals, lead, zinc, nickle, and copper are higher in polluted sediments. High iodine levels indicate that oxidizing conditions are retained at all three stations (N. B. PRICE, pers. comm.). The higher levels of lead, zinc and copper indicate the presence of a greater proportion of organic sludge in the kelp forests at Station 15 (N. B. PRICE, pers. comm.).

From the preceding description of the scant data available on the local physical and chemical conditions in these coastal waters, the following regional differences in water quality can be distinguished: (1) The urbanisation and industrial development of land adjacent to the Firth of Forth has certainly led to pollution of this estuary (also see Sмутн 1968). (2) This estuarine pollution does not extend south to Station 6 (St. Abbs) where the water has oceanic characteristics. (3) Proceeding south from Station 6, a gradient of increasing pollution can be demonstrated which reaches its peak along the shores of Co. Durham. (4) The coastline south from Scarborough to Flambrough Head is reasonably unpolluted but contains high levels of inorganic material in suspension.

\section{Selection of a marine habitat for study}

Sublittoral kelp forests dominated by Laminaria byperborea (GUNN.) FosLE are a constant feature of the extensive rocky out-crops along this length of coast.

Eighteen sampling stations were selected for a study of the characteristic invertebrate epifauna associated with the kelp forest system as shown in Figure 4. The stations are placed to include all known variations in water quality along the coast and are briefly described below. Stations 1 to 4 lie in the polluted Firth of Forth estuary; Stations 5-12 are located in the unpolluted waters of Berwickshire and Northumberland; Stations 13-16 all lie in the chronically polluted waters of Co. Durham; Stations 17 and 19 are located in the unpolluted but naturally turbid waters of North Yorkshire.

\section{METHODS}

A comparison of ecologically equivalent areas was the approach adopted for this study. To successfully apply this technique it is crucial to first establish the equivalence of all sampling units from which data for future comparison are obtained. The habitat provided by hapteron of the kelp forest dominant, Laminaria byperbora was chosen as the sampling unit from which invertebrate communities were enumerated for comparison. This plant is the dominant perennial alga in the North Sea sublittoral rocky ecosystem (JoHN 1968). It can be aged accurately up to seven years (KAIN 1964) and the growth patterns of populations of this plant can be compared (BELLAMY 1968).

Stands of $L$. byperborea occur on rocky outcrops on all the coastline under study and also appear to represent the "climax" vegetation around much of the rocky coasts 
of Europe. Collectively the dense populations of this dominant provide shelter for the development of the associated epifauna. The advantages of this shelter can best be observed in the interstices of the holdfast of large brown algae, where a diverse community of benthic animals becomes established (ANDREws 1925, 1945, YONGE 1958, GELHARDI 1960). Shelter provided by plants is of great importance in the development of a diverse epifauna which will preferentially select areas of seabed which provide it (Shelford \& Towler 1925, Kitching 1934, Drach 1952, Forster 1952, Lilly 1953, 1958 , KNIGHT-JoNEs 1955). The holdfast habitat is thus an ideal microcosm for study as it is easily accessable using an aqua lung, can be completely removed from the rock surface with its epifauna intact, and many of the plants remain in the environment for 7 years or longer.

However, as a biotic unit, it is itself responding to the environment. BELLAMY (1968) has shown that the gross morphology of the stipe and lamina of L. byperborea can be altered and that the productivity of the kelp forest has been reduced by $92 \%$ in the polluted waters of Co. Durham.

An investigation of the growth patterns of the hapteron habitat was therefore necessary to first determine any regional variation in the gross morphology of this part of the plant which might affect the colonization patterns of invertebrates.

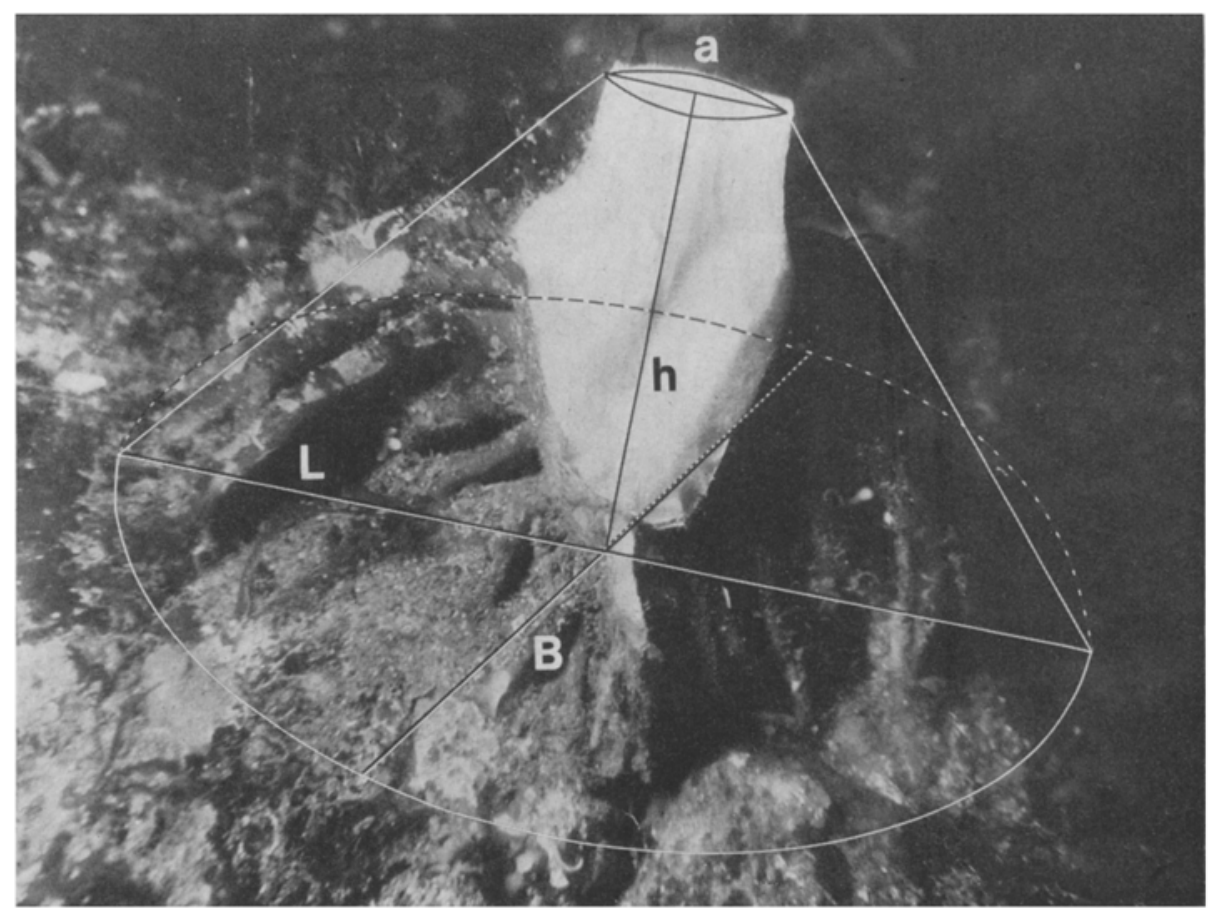

Fig. 5: Median vertical section of holdfast in situ on rock after removal of stipe. Linear dimensions of theoretical volume superimposed. Depth 30', Station 6. (Photo J. Barnes) 
Effects of pollutants on the amount of shelter provided
by Laminaria byperborea holdfast

At a chosen depth, a holdfast was selected, promptly removed from the rock with a sharp knife and placed in a small hessian sack. The sack was quickly closed using nylon drawstrings in the neck and the protruding stipe then cut away.

On return to the laboratory the following morphological characteristics of the holdfast were noted: the length and breadth of the basal part of the holdfast, the vertical height and maximum stipe diameters (Fig. 5). The age of the plant was determined (KAIN 1964).

With a sharp knife successive hapteron whorls were removed starting with the youngest which are highest on the stipe. Stops were made at frequent intervals to remove and collect exposed specimens of the fauna. Detritus and sediment were washed from the cut up holdfast and the weight of the clean dry tissue noted.

A study of the morphology of two thousand holdfasts revealed a basic growth pattern common to all the plants. The base of the holdfast attached to the rock is roughly eliptical and a maximum area that a holdfast occupies can be delimited within that elipse. The annual addition of a whorl of holdfast branches adds not only to the area covered but also to a third dimension, holdfast height. A formula for calculating the maximum amount of euclidian space confining one holdfast can thus be derived.

Area of an elipse $=\pi a b$ where $2 \mathrm{a}=$ major axis and $2 \mathrm{~b}=$ minor axis

Volume of cone height $\mathrm{L}$ eliptical base $=1 / 3 \pi \mathrm{Lab}$

Volume of frustum height $h=1 / 3 \pi[\mathrm{AB}(\mathrm{h}+\mathrm{k})-\mathrm{ab}(\mathrm{K})]$

$$
\begin{aligned}
\frac{\mathrm{k}}{\mathrm{k}+\mathrm{h}} & =\frac{\mathrm{a}}{\mathrm{A}}=-\frac{\mathrm{b}}{\mathrm{B}} \text { is necessary condition } \\
\frac{\mathrm{k}}{\mathrm{k}+\mathrm{h}} & =\frac{\mathrm{a}}{\mathrm{A}} \\
\therefore \mathrm{kA} & =\mathrm{ak}+\mathrm{ah} \\
\therefore \mathrm{k} & =\frac{\mathrm{ah}}{\mathrm{A}-\mathrm{a}}
\end{aligned}
$$

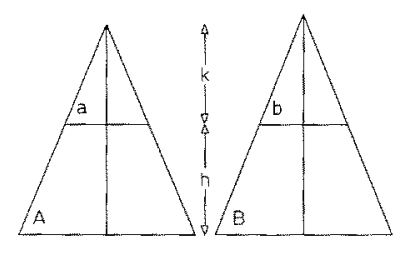

Volume of frustum $=1 / 3 \pi\left[A B\left(h+\frac{a h}{A-a}\right)-\frac{a^{2} b h}{A-a}\right]$

$$
\begin{aligned}
& \left.=1 / 3 \pi \mathrm{h}\left[\mathrm{AB} \frac{\mathrm{A}}{\mathrm{A}-\mathrm{a}}\right)-\frac{\mathrm{a}^{2} \mathrm{~b}}{\mathrm{~A}-\mathrm{a}}\right] \\
& =1 / 3 \pi \mathrm{h} 1 / \mathrm{A}-\mathrm{a}\left[\mathrm{A}^{2} \mathrm{~B}-\mathrm{a}^{2} \mathrm{~b}\right]
\end{aligned}
$$

Substitute for $b, \frac{a B}{A}$

$$
\begin{aligned}
\text { Volume } & =1 / 3 \pi h 1 / A-a\left(A^{2} B-\frac{a^{3} B}{A}\right) \\
& =1 / 3 \pi h \frac{B}{(A-a)}\left[\frac{A^{3}-a^{3}}{A}\right]
\end{aligned}
$$




$$
\begin{aligned}
& =1 / 3 \pi B / A\left(A^{2}+a A+a^{2}\right) \\
& =1 / 3 \pi \frac{B}{A}\left[A^{2}+a A+a^{2}\right] \\
& =1 / 3 \pi \frac{h B}{A}\left[A^{2}+a A+a^{2}\right]
\end{aligned}
$$

Substitute following

$$
\begin{aligned}
& \quad \mathrm{L}=2 \mathrm{~A} \\
& \mathrm{~B}=2 \mathrm{~B} \\
& \therefore \text { Volume }=1 / 3 \pi \mathrm{h} \mathrm{B} / \mathrm{L}\left[\frac{\mathrm{L}^{2}}{4}+\frac{\mathrm{La}}{4}+\frac{\mathrm{a}^{2}}{4}\right] \\
& \quad \text { Volume }=1 / 12 \pi \mathrm{h} \mathrm{B} / \mathrm{L}\left[\mathrm{L}^{2}+\mathrm{La}+\mathrm{a}^{2}\right]
\end{aligned}
$$

The tissue of the holdfast occupies some of this volume. But, total net weight of holdfast tissue $\times \mathrm{Sp}$. Gr. of tissue $=$ Real tissue volume $(\mathrm{ml})$

where $\mathrm{Sp}$. Gr. of L. byperborea tissue is a constant $=1.30$

$\therefore$ [Theoretical holdfast volume] - [Real tissue volume]

$=$ Habitat volume $(\mathrm{ml})$

Thus,

$1 / 12 \pi \mathrm{h} \mathrm{B} / \mathrm{L}\left[\mathrm{L}^{2}+\mathrm{La}+\mathrm{a}^{2}\right]-[$ Wet weight tissue $\times 1.30]$

= Habitat volume, called "ecospace" (ml)

The habitat volume available for invertebrate colonisation is called "ecospace" and can be defined as a measure of the stabilising influence of plant biomass on the range of physical parameters detrimental to faunistic components of the ecosystem. The amount of sheltered habitat available for animal colonisation is thus determined by conversion of measurements of holdfast mass and linear dimension to a single measurement by volume. The age of the plant provides the time scale of ecospace development.

Ecospace measurements, computed for 1450 plants of all ages at all stations along the North East Coast, indicate that the size of the habitat increases throughout the life of the plant. Size, a function of solar energy accumulated as plant tissue, causes the rate of ecospace increase to depend upon the rate of balance between anabolism and catabolism in the plant (Table 3, Fig. 6).

Using logn transformation of ecospace as the $y$ axis, and the minimum age in years as the $\mathrm{x}$ axis, the rate of ecospace increase can be determined by simple linear regression analysis (SNEDOCOR \& COCHRAN 1968) allowing the rate of habitat increase, measured as ecospace to be compared, between spatially distinct populations of Laminaria byperborea. 
Table 3

Dimensions of holdfasts used for calculating ecospace

\begin{tabular}{|ccccccc|}
\hline $\begin{array}{c}\text { Age } \\
\text { (years) }\end{array}$ & $\begin{array}{c}\text { Length } \\
(\mathrm{cm})\end{array}$ & $\begin{array}{c}\text { Breadth } \\
(\mathrm{cm})\end{array}$ & $\begin{array}{c}\text { Height } \\
(\mathrm{cm})\end{array}$ & $\begin{array}{c}\text { Wet } \\
\text { weight } \\
(\mathrm{g})\end{array}$ & $\begin{array}{c}\text { Stipe } \\
\text { diameter } \\
(\mathrm{cm})\end{array}$ & $\begin{array}{c}\text { Ecospace } \\
(\mathrm{ml})\end{array}$ \\
\hline 1 & $2.3 \pm 0.0$ & $1.5 \pm 1.2$ & $0.8 \pm 0.1$ & $1.1 \pm 1.3$ & $0.5 \pm 0.2$ & $0.0 \pm 0.2$ \\
2 & $4.1 \pm 0.2$ & $3.0 \pm 0.1$ & $1.9 \pm 0.0$ & $5.0 \pm 0.0$ & $1.3 \pm 0.0$ & $2.7 \pm 0.1$ \\
3 & $6.9 \pm 0.0$ & $5.2 \pm 0.0$ & $2.2 \pm 0.3$ & $21.0 \pm 1.4$ & $1.7 \pm 0.0$ & $10.2 \pm 1.3$ \\
4 & $10.2 \pm 0.2$ & $7.5 \pm 0.2$ & $3.4 \pm 0.0$ & $47.5 \pm 2.7$ & $2.5 \pm 0.0$ & $36.4 \pm 3.9$ \\
5 & $14.3 \pm 0.3$ & $10.1 \pm 0.3$ & $4.9 \pm 0.1$ & $113.8 \pm 5.3$ & $2.9 \pm 0.0$ & $92.6 \pm 6.7$ \\
6 & $16.5 \pm 0.2$ & $12.7 \pm 0.2$ & $6.0 \pm 0.1$ & $178.0 \pm 6.8$ & $3.2 \pm 0.0$ & $186.2 \pm 17.3$ \\
7 & $18.7 \pm 0.3$ & $13.9 \pm 0.9$ & $7.8 \pm 0.1$ & $274.9 \pm 12.0$ & $3.8 \pm 0.0$ & $312.1 \pm 19.6$ \\
\hline
\end{tabular}

Figure 7 presents the regression analysis on the mean rate of ecospace increase for the polluted and unpolluted stations. " $F$ " tests on the mean variance of the annual rate of ecospace increase in polluted and unpolluted water show no significant differences between polluted and unpolluted stations. Hence the amount of ecospace produced and the rate at which it is formed during the life of an average individual remain equal in the polluted and unpolluted areas.

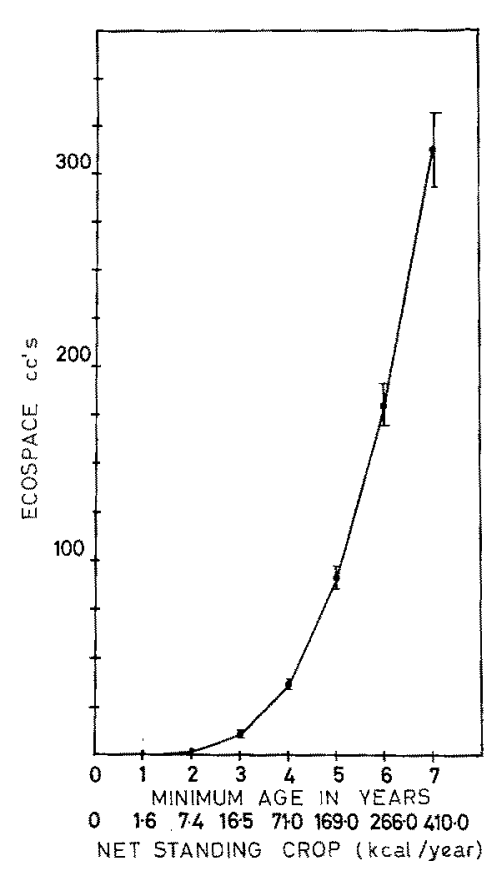

Fig. 6

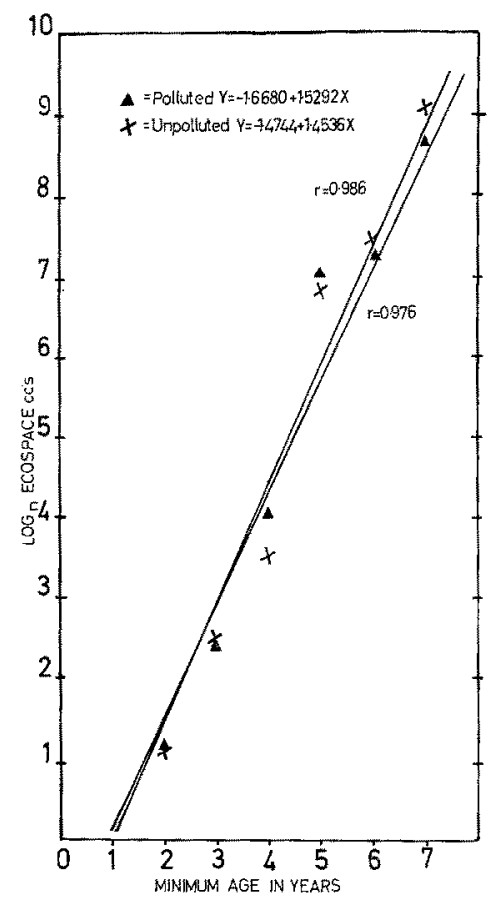

Fig. 7

Fig. 6: Increase in ecospace with time and standing crop of holdfast tissue

Fig. 7: Mean rate of ecospace increase at all the unpolluted stations compared with all the polluted stations 
Polluted kelp forests in the North Sea

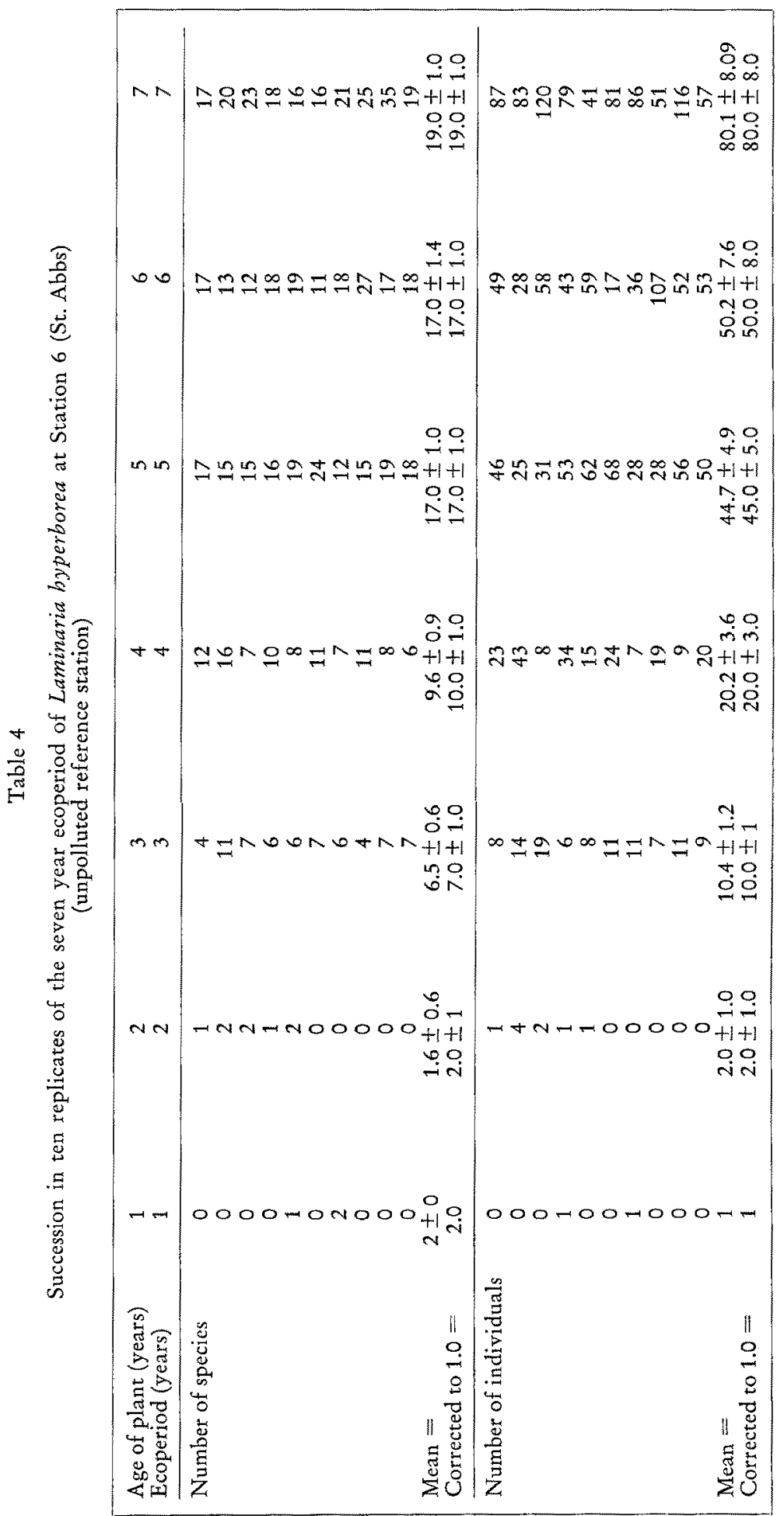




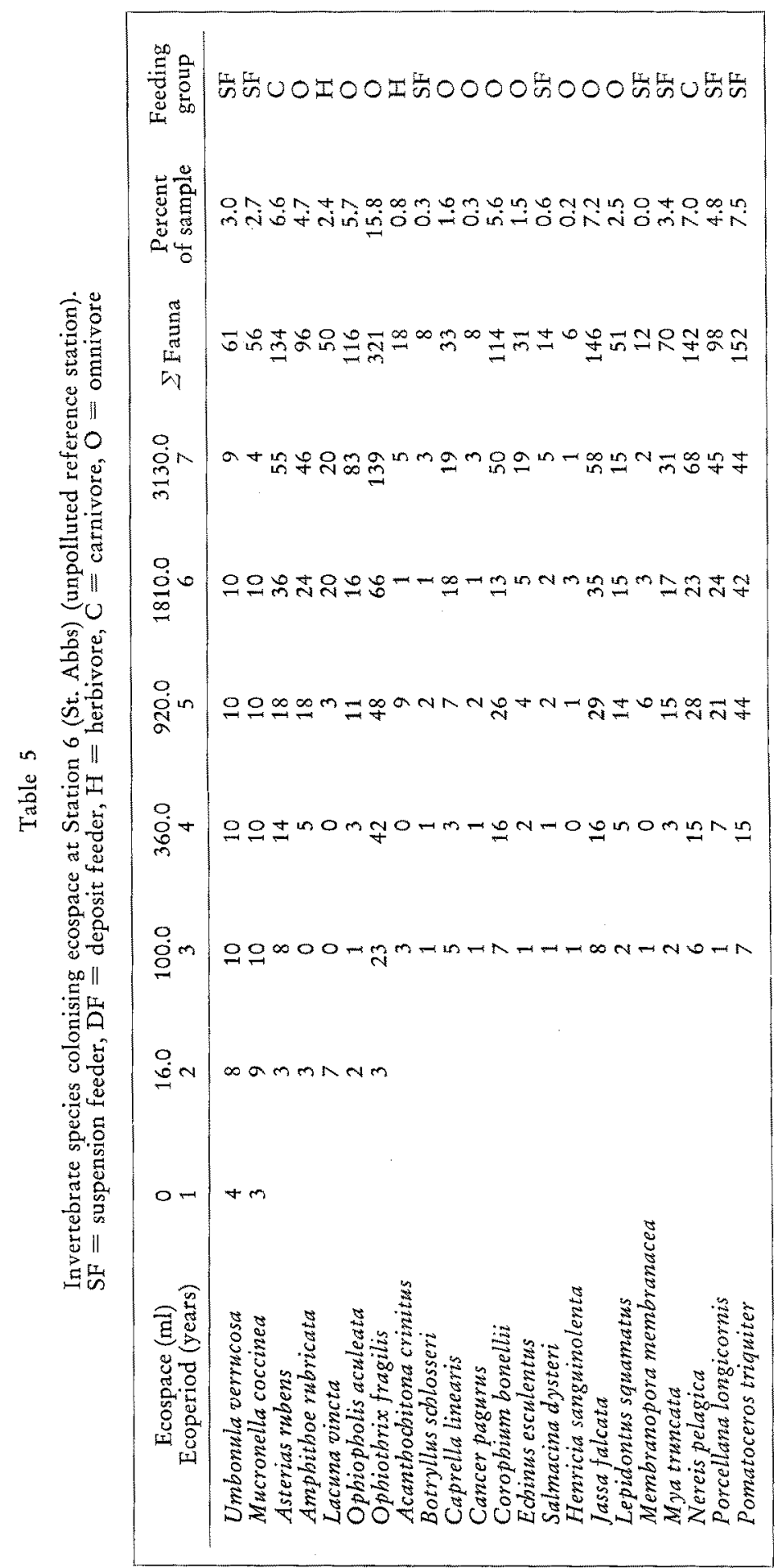


Polluted kelp forests in the North Sea

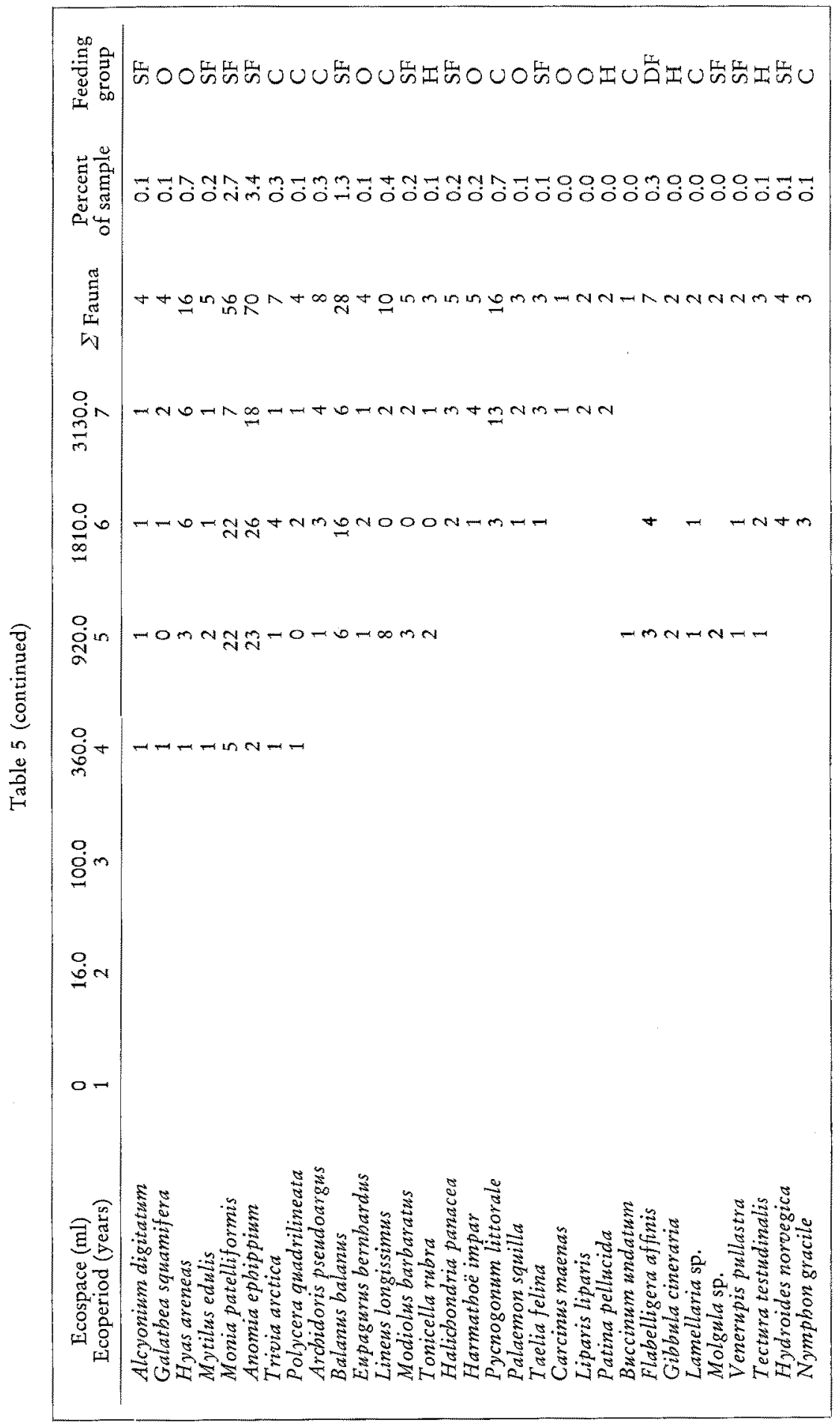


By sampling plants in all age classes from one to seven years old, the gradual increase in the dimensions of the habitat can be determined. Within the North East Region, spatial and temporal comparisons of communities developed in these similar habitats were then made.

\section{RESULTS}

The ecospace habitat as a sampling unit for invertebrates

Elements of the epifauna which are dispersed throughout the kelp forest, colonise the ecospace habitat. Community data obtained from ten replicates of the seven year ecoperiod is presented in Table 4. This information is collected for Station 6 (St. Abbs) an established clean water reference point for further comparative studies on pollution. The mechanics of community development found here are taken as the normal state of affairs in the ecospace microcosm.

The number of species included in the habitat increases as ecospace increases, as indicated in Table 4. After the first period when only two species settle, there follows a steady accumulation of new species. By the seventh and final ecoperiod $19.0 \pm 1.0$ species totaling $80.0 \pm 8.0$ individuals are present. Of the total number of 53 species present, 44 are recruited into the habitat in a distinct series and almost without exception remain in the community, gradually increasing in numbers for the duration of habitat development.

The feeding patterns of the developing community change as the habitat enlarges (Table 5). The encrusting suspension feeders Umbonula verrocosa and Mucronella coccinea, pioneer the colonisation, but lose their initial dominance in succeeding ecoperiods.

In the second ecoperiod, omnivores Amphithoe rubricata, Opbiopholis aculeata, Opbiotbrix fragilis, the herbivore, Lacuna vincta and the carnivore Asterias rubens appear as the first members of alternative feeding groups. The deposit feeder Flabelligera affinis completes the complement of five major invertebrate feeding groups (JonEs 1970), by the end of the 5 th ecoperiod. Considering the community as one "superorganism" (c.f. BoDENHEIMER 1938) it thus seems that community development can take 5 successive ecoperiods to develop to maturity and that pioneer species are encrusting forms which feed on suspended material borne past the habitat by water movements.

Thus the developing ecospace habitat is subject to at least two biotic factors which influence the developing community: the growth patterns of the plant which provides the habitat and the presence of other invertebrate species already in the habitat. A distinct sequence of colonisation by a series of species is the result. This process bears some resemblance to succession (TANSLEY 1953, ODUM 1959). With little or no knowledge of the life histories of most of the invertebrates involved in this study, further ecological interpretation of a sequenced colonisation in this habitat must be approached with caution. It is unlikely that many of the mobile species remain in one holdfast for six or seven calendar years, whilst the sessile forms will not be uniformly distributed by successive spatfall. 
Polluted kelp forests in the North Sea

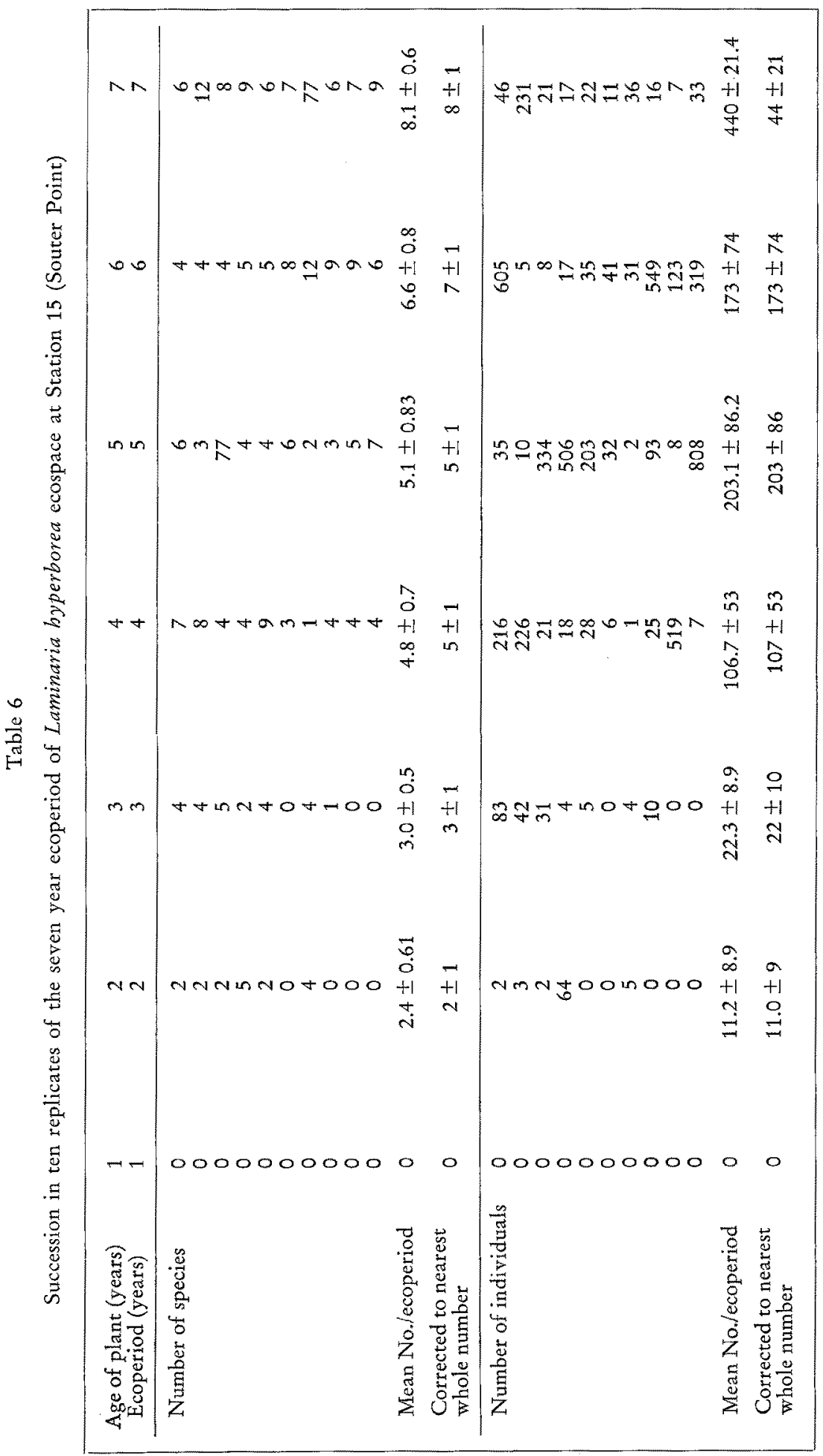


The term "ecoperiod" is used to describe the rate of invertebrate colonisation in ecospace. The rate of ecospace enlargement is measured by the age of the plant. By sampling all stages of habitat development at one point in time, the proportion of the different species accumulated in ecospace depicts the accomodation of communities to environmental conditions prevailing in the vicinity of the habitat. The sequence of colonisation over seven successive ecoperiods can thus be considered as an historical account of community development in ecospace.

\section{The ecospace habitat in polluted waters}

Community data for ten sets of the seven year ecoperiod collected at Station 15 (Souter Point) are presented in Table 6. This station is one of the most polluted areas in the study. It is located 120 miles south of Station 6.

The number of species included in the polluted water habitat is low (Table 6). After the first annual ecoperiod, two species settle. A slow rate of species accumulation takes place which, by the end of the seventh ecoperiod, amounts to only eight species. The rate of accumulation of individuals is faster, reaches maximum by the 5 th ecoperiod when 200 individuals are present. By the seventh ecoperiod only 44 individuals are present in the fully developed habitat. A total of 44 species attempt colonisation of which only 27 species become progressively and permanently included. The remaining 17 species make only a sporadic appearance in the community.

The feeding patterns of the developing community undergo some change during development (Table 7). One encrusting suspension feeder Haliocbondria panacea and the bivalve Mytilus edulis pioneer habitat colonisation in the first ecoperiod, but did not lose there initial dominance as large numbers of Mytilus edulis continued to colonise the habitat during all stages of its development. By the third ecoperiod, small numbers of deposit feeders, herbivores, carnivores and omnivores appeared in the community to complete the trophic complement. Of the five alternative trophic groups which colonise ecospace, only carnivores appear as a significant community element accompying the dominant suspension feeders.

\section{Comparison of "succession" in polluted and unpolluted ecospace at Stations 6 and 15}

In polluted waters at Station 15 the number of species colonising the habitat is reduced by $43 \%$ (Fig. 8). In both cases, a successive series of species colonised the habitat as it enlarged. In polluted water, the partern of this increase is dissimilar. Maximum numbers of species were rapidly attained by the 5 th ecoperiod whereupon some process caused the numbers of individuals to decline even though the habitat continued to enlarge (Fig. 9). In clean waters, by comparison, fewer individuals were found in the habitat but these steadily increased in numbers as the habitat developed to full size. The species diversity of the polluted community is thus reduced but the rate of colonisation is speeded up by two annual ecoperiods. 


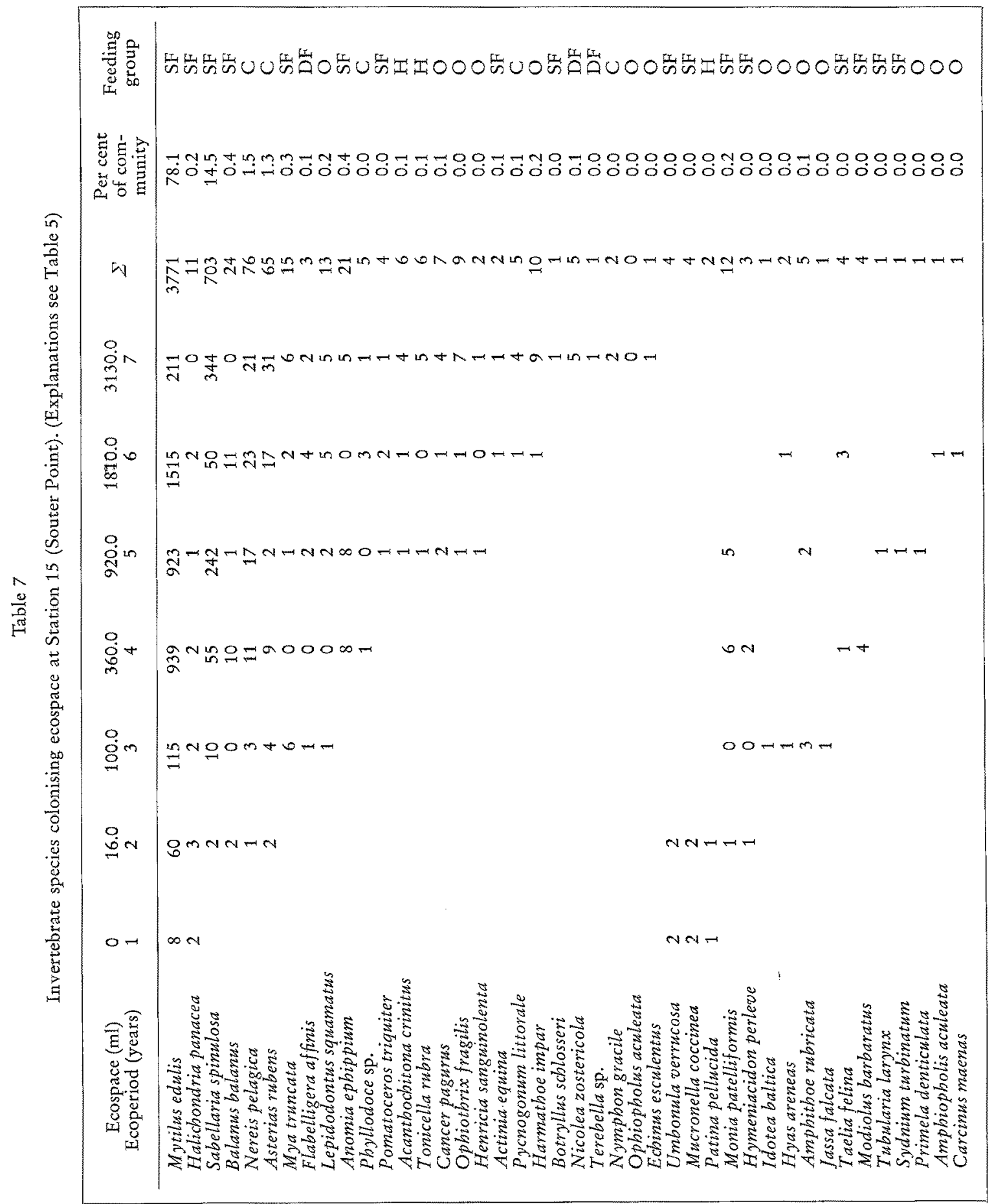


A different sequence of species colonised the habitat in polluted waters and pioneer species of suspension feeders retained there dominance over other trophic groups, throughout community development. The trophic complexity of the community becomes reduced to a suspension feeding unit, which is accompanied by some carnivores, as shown in Figure 10.

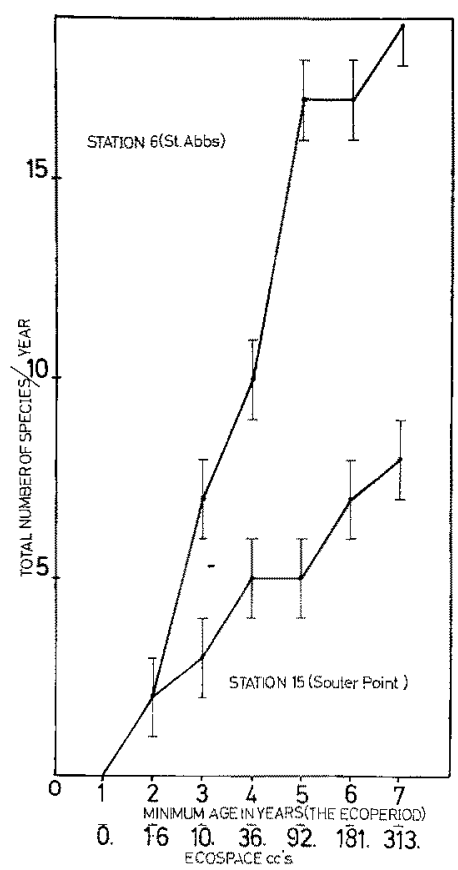

Fig. 8

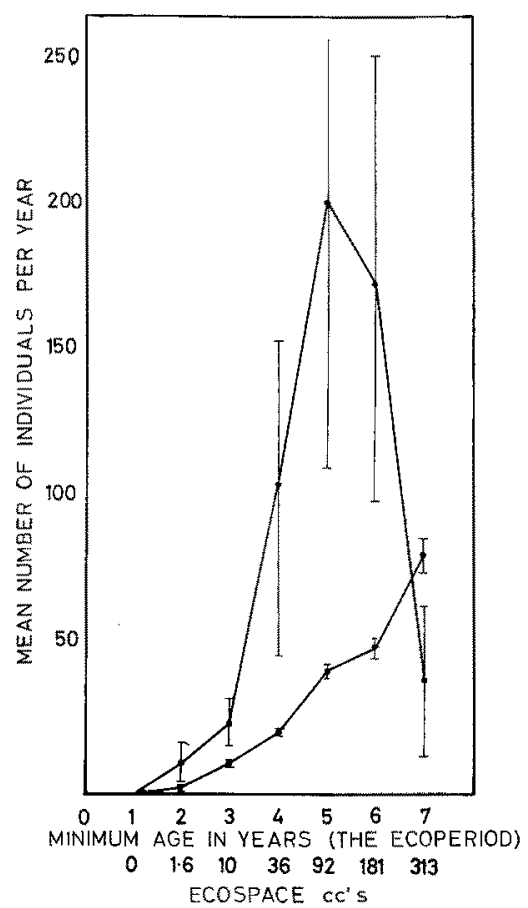

Fig. 9

Fig. 8: Comparison of rate of colonisation by new species at Station 6 (unpolluted reference station) and Sation 15 (chronically polluted)

Fig. 9: Comparison of rate of colonisation by individuals of all species at stations 6 and 15

\section{DISCUSSION}

A consideration of the whole community, during all its stages of development to maturity indicates that many of the species described by Peterson (1915), Gislen (1931), Spark (1937), Einarsson (1941) and Jones (1950) become part of the ecospace community. This typical epifaunal association known as the 'Modiolus modiolus' or 'Mytilus edulis' biome, can be dominated by the species Ophiotbrix fragilis, Ophiopholis aculeata, Porcellana longicornis, Balanus sp., Galatbea sp. and a range of annelids (Jones 1950). This species configuration on the shallow water rocky benthos, is known for most northwest European clear water, rocky shores, including those of Iceland, Denmark, Sweden, the Baltic and the North Sea. 
As far as can be determined, an exact similar habitat is available for colonisation in the polluted waters yet atypical community development takes place within it. In polluted waters, larger, simpler communities developed faster but retained juvenile
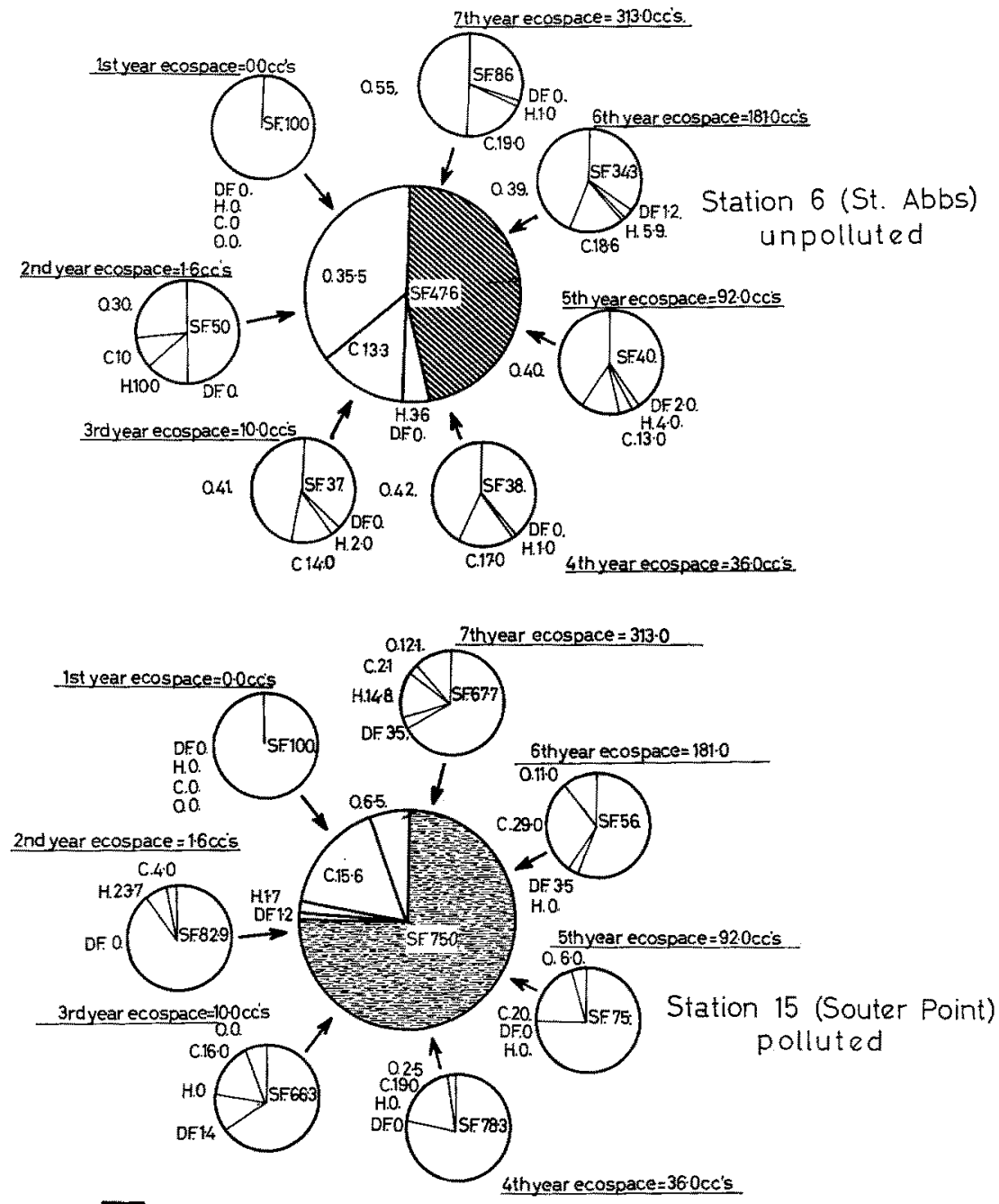

Mean number of suspension feeders

Fig. 10: Percentage of five major feeding groups present in succeeding ecoperiods. Mean of each feeding group for the seven annual ecoperiods at centre

species as community dominants in the mature stages of habitat development. The invertebrate community can be regarded as undergoing neotenous development, characterized by the absence of any complexity in space or time. The following features may be recognized as neotenous characteristics of the polluted water system: 
(1) There is an unusually large potential energy source available in the form of sewage pollution. The ecosystem response to this increased energy source is a reduction in species diversity and complexity (c.f. Margalef 1968). (2) Suspension feeding is an unspecialized mechanism compared with the more specialized methods of herbivores, carnivores and omnivores and as such can be considered as a more juvenile method of feeding (Margalef 1967a). (3) A pioneer species Mytilus edulis remains dominant in the community from the earliest (most juvenile) stages of its development. This species has a high level of fecundity (SEED 1968) which is a necessary quality for pioneering species in new situations. Successful in juvenile communities, it continues to dominate all subsequent stages of community development to maturity. (4) The planktonic larvae of Mytilus edulis can remain free floating for many weeks (SEED 1968). This ensures wide dispersal and further increases the chances of successful colonisation in new habitats.

Thus, the community response to pollution along the shores of Co. Durham involved a modification of the 'old' system developed in natural waters, by a recombination of existing species formerly present in small numbers. Many species have been lost in this process but no pollution dependant species have appeared. The new community can be thought of as an utility system stripped bare of many superfluous energy pathways. It makes use of a new and readily available food source. A fine suspension of sewage solids sweeps through the kelp forest, borne on water movements. PAINTER \& VARNEY (1959) have shown that up to $70 \%$ of sewage poured into the sea can remain in suspension. A large suspension feeding population containing species resistant to other industrial effluents in the water, occupies ecospace in these areas.

The exact reasons for the fragmented and retarded succession which occurs in polluted waters are not known. However, the absence of half the clean water species in polluted water ecospace must play its part. An ecological barrier is in operation here which restricts the access of many clean water species.

To be 'successful' it appears that each species must become permanently integrated into the community in a nonrandom sequence not unlike succession. Fifteen species which attempt the initial colonisation of the polluted habitat, fail to obtain a permanent foothold. The presence of these species in polluted waters indicates that as individuals they are able to withstand the stress of pollution but their inability to become integrated prevents them from taking a central role in community development. A second ecological barrier is thus operating, subordinating these species to a marginal role.

Further investigations are now necessary on the ecophysiological responses of species which are excluded from polluted waters or are only marginally present. It is apparent that at least two ecological barriers seriously disrupt the natural sequence of community development in polluted ecospace.

\section{SUMMARY}

1. The English Counties of Midlothian and Durham are situated on the North Western Edge of the North Sea. Both counties have a high population density and a variety of industries located in them. 
2. The coastal seas adjacent to these areas are heavily polluted.

3. In one of these industrial areas, County Durham, the coastal waters have been polluted for 150 years - from the beginning of the Industrial Revolution.

4. Two gradients of pollution, one estuarine and one off the open coast, are described. The intervening sea coast has little or no pollution.

5. A comparative method of pollution surveying is presented which makes use of the epifauna in the holdfast or hapteron of the large brown alga Laminaria byperborea (Gunn.) Fost.

6. The size of the habitat is measured in cubic millilitres and called ecospace.

7. The rate of invertebrate colonisation is measured in ecoperiods.

8. Statistical investigation reveals similar habitats in clean and polluted water.

9. The 'normal' sequence of habitat colonisation by invertebrates is described for clean waters. It contains species groups commonly found on rocky sublittoral kelp forests elsewhere in the North Atlantic.

10. Ecological comparison is made of the community development described for clean and polluted stations.

11. Results indicate that in polluted water, invertebrate 'succession' is retarded; the species composition of the community is simplified, $43 \%$ of the species are lost, rates of habitat colonisation by individuals of pollution tolerant species are speeded up; the polluted community undergoes neotenous development i.e. retaining juvenile characteristics throughout development to community maturity.

12. Functional aspects of 'new' (pollution present) and 'old' (pollution absent) communities are discussed.

13. The marginal presence of some species in polluted water is also discussed.

15. Two ecological barriers to normal community development in the polluted environment are postulated.

Acknowledgements. I wish to thank the University of Durham for the award of a research studentship which made this project possible, and Professor D. Boulter who provided working facilities in the Department of Botany. This work was conducted in fulfilment of the $\mathrm{Ph}$. D. requirements of the University. I am indebted to my supervisor Dr. D. J. BeLLAMY for his help and guidance with all aspects of this study. Without the cheerful help and cooperation of the following people, an extensive field survey would not have been possible: Dr. G. Moore, University of Leeds, Welcome Marine Laboratories, Robin Hoods Bay, who identifed many of the invertebrate species; Dr. J. LEWIs, Director, Welcome Marine Laboratories for the provision of working facilities at his station; Dr. P. C. HEAD, University of Newcastle-UponTyne, Department of Public Health and Engineering who undertook most of the seawater analysis; Dr. N. B. PrICE, Grant Institute of Geology, University of Edinburgh who analysed the sediments; Mr. P. OGDen, University of Durham, Department of Theoretical Physics for his help with the "ecospace" formulation, and Mr. E. WALKER, my diving partner who was financed by an N.E.R.C. grant, Professor J. W. House, Department of Geography, University of Newcastle-Upon-Tyne and David and Charles (Holdings) Ltd. for permission to include Figures 2 and 3. This work forms part of the International Biological Program (Productivity Marine).

\section{LITERATURE CITED}

Andrews, H., 1925. Animals living on kelp. Publs Puget Sound mar, biol. Stn. 5, 25-27. - 1945. The kelp beds of the Monterey Region. Ecology 26 (1), 24-37. 
Bellamy, D. J., 1968. Effects of pollution on the marine plant life of the Teesmouth Area. In: Watson \& Watson, Teeside sewage and sewage disposal. Final Report, Appendix 1, p. 103-107.

- \& Whrt ICK, A., 1968. Problems in the assessment of the effects of pollution on inshore marine ecosystems dominated by attached macrophytes. Field Studies Council Publ., Suppl. to Vol. 2.

Bodenheimer, F. S., 1938. Problems of animal ecology. Oxford.

Covit, R. A., Davies, A. W. \& Chandler, J. R., 1968. Parameters of marine pollution in the Forth Estuary. Publ. Wks. Municip. Ser. Cong. Inst. Water Poll Count. 16.

Cronin, E., 1967. The role of man in eastuarine processes. In: Estuaries, Ed. by G. H. LaufF. Am. Assn. Adv. Sci., Washington, 667-689.

Drach, P., 1952. Lacunes dans le connaissance du peuplement des mers et utilisation des scaphandres autonomes. Revue scient., Paris 90, 58-72.

Einarsson, H., 1941. Survey of the benthonic animal communities of Faxa Bay (Iceland). Meddr Kommn Danm. Fisk.-og Havunders. (Ser. Fiskeri) 11 (1), 1-46.

FORSTER, G. R., 1952. Underwater observations on the fauna of the rocky areas in the neighbourhood of Plymouth. J. mar. biol. Ass. U.K. 38, 361-367.

- 1958. Ecology of Echinus esculentus (L.). Quantitative distribution and rate of feeding. J. mar. biol. Ass. U.K. 33, 341-344.

Gamulin-Brida, H., Graccone, G. \& Golubić, S., 1967. Contribution aux études des biocoenoses subtidales. Helgoländer wiss. Meeresunters. 15, 429-444.

GHerlardi, R. J., 1960. Structure and dynamics of the animal community found in Macrocyistis pyrifera holdfasts. $\mathrm{Ph}$. D. Thesis. Scripps Instn Oceanogx., La Jolla, Calif.

Gislen, T., 1930. Epibiosis of Gullmar Fjord. Christinebergs Zoologica Stn. 1867-1927, Uppsala $4,1-1360$.

HARveY, W. H., 1945. Recent advances in the chemistry and biology of sea water. Cambridge Univ. Press, London, 164 pp.

House, J. W., 1969. Industrial Britain - the North East. David \& Charles, Exeter, 250 pp.

JEFFRIEs, H. P., 1962. Environmental characteristics of Raritam Bay, a polluted estuary. Limnol. Oceanogr. 7, 21-31.

JoHn, D. M., 1968. Studies on littoral and sublittoral ecosystems. Ph. D. Thesis, Univ. of Durham, England.

JonEs, D. J., 1970. Ecological studies on the fauna inhabiting the hapteron of the kelp plant Laminaria byperborea (Gunn.) Fosle. Ph. D. Thesis, Univ. of Durham, England.

JoNes, N. S., 1950. Marine bottom communities. Biol. Rev. 25, 283-313.

KanN, J. M., 1964. Aspects of the biology of Laminaria byperborea. II. Age. Weight. Length. J. mar. biol. Ass. U.K. 43, 129-151.

KaLLE, K., 1954. Der Einfluß des englischen Küstenwassers auf den Chemismus der Wasserkörper in der südlichen Nordsee. Ber. dt. wiss. Kommn Meeresforsch. 13, 130-135.

Kitching, J. A., Macan, T. T. \& Gilson, H. C., 1934. Studies on sublittoral ecology. 1. A Submarine Gully in Wembry Bay, Devon. J. mar. biol. Ass. U.K. 19, 677-705.

KNIGHT-Jones, E. W. \& Jones, W. C., 1955. The fauna of the rocks at various depths off Bardsey. II. Sponges, invertebrates and bryozoans. Rep. Bardsey Bird Fld Obs. 5, 1-8.

Koch, P., 1959. Discharge of waste into the sea in European coastal waters. Proc. Int. Conf. Waste Dispos. mar. Envir. 1, 122-130.

LinLY, S. J., 1953. The ecology of Loch Ine Rapids with special reference to water currents (iv). The sedentary fauna of sublittoral boulders. J. Anim. Ecol. 22, 87-122.

Margalef, R., 1967. The food web in the pelagic environment. Helgoländer wiss. Meeresunters. 18, 548-549.

- 1968. Perspectives in ecological theory. Univ. of Chicago Press, Chicago, 111 pp.

Onum, E. P. \& Opum, H. T., 1959. Fundamentals of ecology. Sanders, London, 546 pp.

ODum, H. T. \& ODum, E. P., 1961. Factors which regulate productivity and heterotrophic utilisation in the ecosystem. Trans. 1960. Seminar TAFT. Sanit. Eng. Cent. Tech. Rep. W 61-3, 65-71. 
Painter, H. A. \& Varney, M., 1959. Composition of domestic sewage. J. biochem. microbiol. Technol. Engng. 1, 143-162.

Peterson, C. John., 1915. On the animal communities on the sea bottom in the Skagerrak, the Christiania Fjord, and the Danish waters. Rep. Dan. biol. Stn 23, 3-28.

Raymont, J. E., 1963. Plankton and productivity of the oceans. Academic Press., London, $660 \mathrm{pp}$.

Rees, C. B., 1939. The plankton of the upper reaches of the Bristol Channel. J. mar. biol. Ass. U.K. $23,397-425$.

Renn, C. E., 1956. Man as a factor in the coastal environment. Trans. N. Am. Wildl. Conf. 21, $470-473$.

Rrley, G. A., 1937. Significance of the Mississippi River drainage for biological conditions in the Gulf of Mexico. J. mar. Res. 1, 67-87.

SEED, R., 1969. The ecology of Mytilus edulis (L.) (Lamellibranchiata) on exposed rocky shores. 1. Breeding and settlement. Oecologia. 3, 277-316.

Shelford, V. E. \& Towler, E. D., 1925. Animal communities of the San Juan Channel and adjacent waters. Publs Puget Sound mar. biol. Stn 5, 31-73.

SмYтH, H. C., 1968. The fauna of a polluted shore in the Firth of Forth. Helgoländer wiss. Meeresunters. 17, 216-223.

Snedecor, G. W. \& Cochran, G., 1968. Statistical methods. Iowa State Univ. Press, Ames, Ia., 593 pp.

SPARK, R., 1937. The benthoic communities of the coastal waters. Zoology Iceland 1 (6).

Tansley, A. G., 1953. The British islands and their vegetation. Cambridge Univ. Press, Cambridge, $930 \mathrm{pp}$.

Watson, J. D. \& Watson, D. M., 1968. Teeside sewage and sewage disposal. Final Report.

YoNeE, C. M., 1958. The sea shore. Collins., London, 311 pp.

Author's address: Dr. D. J. Jones

Department of Biological Sciences

Simon Fraser University

Burnaby 2, B.C.

Canada 